\title{
A Emenda Constitucional 57 E A CONVALIDAÇÃO DA DECLARAÇÃO DE INCONSTITUCIONALIDADE
}

\author{
Constitutional Amendment 57 and the convalidation \\ of the unconstitutionality declaration
}

\section{Olavo Augusto Vianna Alves Ferreira}

Doutor e Mestre em Direito do Estado pela PUC-SP. Coordenador do Curso de Direito da Unaerp, onde é Professor de Direito Constitucional da graduação e do Programa de Mestrado. Professor convidado de cursos de pós-graduação (PUC-Cogeae, UFBA, Escola Superior do Ministério Público, JusPodivm e Faap). Procurador do Estado de São Paulo.

\section{Luciana Campanell Romeu}

Mestre em Direito Público pela Unesp. Professora de Direito Constitucional. Advogada.

Recebido em: 01.03.2012

Aprovado em: 03.04.2012

ÁreA do DIReITo: Constitucional; Processual

Resumo: Com o advento da EC 15, o art. 18, § 4. ${ }^{\circ}$ da CF/1988 passou a exigir Lei Complementar federal para viabilizar a instauração de processos tendentes à criação, à incorporação, à fusão e ao desmembramento de municipalidades. Diante a ausência de efetiva deliberação e aprovação da referida Lei Complementar federal até a presente data, mais de 50 Municípios foram criados sem
AвSTRACT: With the advent of the Constitutional Amendment 15, art. 18, § 4. ${ }^{\circ}$, of the Federal Constitution, it has been required complementary federal law to enable the establishment of processes for the creation, incorporation, merging, and dissolution of municipalities. Facing the absence of effective deliberation and approval of this federal complementary law to this date, 
observância da norma constitucional em comento. A inércia do legislador foi reconhecida pelo STF que declarou a inconstitucionalidade de diversas leis estaduais, $\mathrm{e}$, a inconstitucionalidade da omissão legislativa. Veio a EC 57/2008, que pretendeu convalidar os atos de criação, fusão, incorporação e desmembramento de Municípios, cuja lei tenha sido publicada (até 31.12.2006) ao arrepio da Constituição. Discute-se a validade da Emenda Constitucional que convalida ato inconstitucional e a possibilidade desta perpetuar, de forma válida, os efeitos do ato inconstitucional.

Palavras-chave: Convalidação de ato inconstitucional - Efeitos do ato inconstitucional Emenda Constitucional - Separação de poderes. more than 50 municipalities were created with no complying of the constitutional provision under discussion. The inertia of the legislator was recognized by the Supreme Federal Court which declared the unconstitutionality of several state laws and the unconstitutionality of the legislative omission. Then the Constitutional Amendment $57 / 2008$ has come seeking to validate the acts of creation, merging and dissolution of municipalities, whose law has been published (before 31.12.2006) in defiance of the Constitution. A discussion has been raised about the validity of the Constitutional Amendment which validates the unconstitutional act and the possibility of perpetuating, validly, the effects of the unconstitutional act.

KeYwords: Convalidation of an unconstitutional act - The effects of an unconstitutional act - Constitutional Amendment - Separation of powers.

SumÁRıo: 1. Introdução - 2. 0 princípio da nulidade do ato inconstitucional - 3. Inconstitucionalidade por violação ao art. 18, § 4. ${ }^{\circ}$, da CF/1988 - 4. A EC 57 e a convalidação da declaração de inconstitucionalidade: 4.1 A convalidação do ato inconstitucional; 4.2 Competência do Legislativo para perpetuar os efeitos do ato declarado inconstitucional pelo STF? - 5. Conclusão - 6. Bibliografia.

\section{INTRODUÇÃO}

Com o advento da EC 15, de 12.09.1996, o art. 18, § 4. ${ }^{\circ}$, da CF/1988, passou a determinar que: "A criação, a incorporação, a fusão e o desmembramento de Municípios, far-se-ão por lei estadual, dentro do período determinado por lei complementar federal, e dependerão de consulta prévia, mediante plebiscito, às populações dos Municípios envolvidos, após divulgação dos Estudos de Viabilidade Municipal, apresentados e publicados na forma da lei" (grifo nosso).

Ocorre que, não obstante se tratar de norma constitucional de eficácia limitada, adotando a classificação de José Afonso da Silva, ${ }^{1}$ até a presente data não houve efetiva deliberação e aprovação da referida Lei Complementar federal.

1. Aplicabilidade das normas constitucionais. 6. ed. São Paulo: Malheiros, 2003. 
A inércia do legislador neste caso foi reconhecida pelo STF que declarou a inconstitucionalidade de diversas leis estaduais posteriores à EC $15,{ }^{2}$ e, a inconstitucionalidade da omissão legislativa, ${ }^{3}$ conforme veremos adiante.

Consoante noticiou o site do STF, mais de 50 Municípios foram criados sem observância do art. 18, § 4. ${ }^{\circ}$, da CF/1988. ${ }^{4}$

Neste contexto veio a EC 57, de 18.12.2008, ${ }^{5}$ que pretendeu "convalidar os atos de criação, fusão, incorporação e desmembramento de Municípios", cuja lei tenha sido publicada (até 31.12.2006) ao arrepio da Constituição.

Surgem as questões objeto do presente trabalho: é válida Emenda Constitucional que convalida ato inconstitucional? A Emenda Constitucional pode validamente perpetuar os efeitos do ato inconstitucional?

Buscaremos apreciar o princípio da nulidade do ato inconstitucional, o reconhecimento pelo STF da inconstitucionalidade de leis estaduais nos termos do art. 18, § 4. ${ }^{\circ}$ em epígrafe, e da omissão legislativa, bem como, a constitucionalidade da EC 57/2008.

\section{O PRINCÍPIO DA NULIDADE DO ATO INCONSTITUCIONAL}

Tecidas estas breves considerações introdutórias acerca da ausência da Lei Complementar exigida pela Constituição para a criação, a incorporação, a fusão e o desmembramento de Municípios, e da tentativa pela EC 57/2008 de convalidar os consequentes atos inconstitucionais, necessárias algumas palavras acerca do princípio da nulidade do ato inconstitucional para este estudo.

2. ADIn 3.316/MT, rel. Min. Eros Grau, DJ 29.06.2007; ADIn 3.489/SC, rel. Min. Eros Grau, DJ 03.08.2007; ADIn 3.689/PA, rel. Min. Eros Grau, DJ 26.09.2008.

3. ADIn 3.682/MT, rel. Min. Gilmar Mendes, DJ 06.09.2007.

4. Disponível em: [www.stf.jus.br/portal/cms/verNoticiaDetalhe.asp?idConteudo=1065 $01 \&$ caixaBusca=N]. Acesso em: 16.07.2010.

5. EC 57, de 18.12.2008:

"Acrescenta artigo ao Ato das Disposições Constitucionais Transitórias para convalidar os atos de criação, fusão, incorporação e desmembramento de Municípios.

As Mesas da Câmara dos Deputados e do Senado Federal, nos termos do § 3. ${ }^{\circ}$ do art. 60 da Constituição Federal, promulgam a seguinte Emenda ao texto constitucional: Art. $1 .^{\circ} \mathrm{O}$ Ato das Disposições Constitucionais Transitórias passa a vigorar acrescido do seguinte art. 96:

'Art. 96. Ficam convalidados os atos de criação, fusão, incorporação e desmembramento de Municípios, cuja lei tenha sido publicada até 31 de dezembro de 2006, atendidos os requisitos estabelecidos na legislação do respectivo Estado à época de sua criação.'

Art. 2. ${ }^{\circ}$ Esta Emenda Constitucional entra em vigor na data de sua publicação." 
A Constituição não previu expressamente a sanção cominada ao ato inconstitucional, ${ }^{6}$ sendo que a forma de enfrentar o problema foi absorvida do direito norte-americano, ${ }^{7}$ matriz do nosso sistema de controle. ${ }^{8}$

Assim, pertence à tradição jurídica brasileira ${ }^{9}$ a teoria da nulidade da lei inconstitucional, fundada no aforismo pelo qual "inconstitucional statute is not law at all". ${ }^{10}$

Firmou-se o dogma da nulidade da lei inconstitucional na doutrina e na jurisprudência do $\mathrm{STF}^{11}$ conferindo-se à declaração de inconstitucionalidade

6. A inconstitucionalidade é vício, que "não se confunde, vale ressaltar, com a sanção de inconstitucionalidade, que é a consequência estabelecida pela Constituição para a sua violação: a providência prescrita pelo ordenamento para a sua restauração, a evolução do vício rumo à saúde constitucional. Caso essa evolução não se verifique espontaneamente ou dependa de intervenção coativa, far-se-á uso dos remédios constitucionais, ou seja, dos instrumentos de garantia compreendidos no chamado controle de constitucionalidade" (Elival da Silva Ramos. A inconstitucionalidade das leis: vício e sanção. São Paulo: Saraiva, 1994. p. 63-64).

7. Ana Paula Oliveira Ávila. A modulação de efeitos temporais pelo STF no controle de constitucionalidade. Porto Alegre: Livraria do Advogado, 2009. p. 39.

8. Gilmar Ferreira Mendes; Inocêncio Mártires Coelho; Paulo Gustavo Gonet Branco. Curso de direito constitucional. 3. ed. São Paulo: Saraiva, 2008. p. 1099.

9. Ruy Barbosa. Os atos inconstitucionais do Congresso e do Executivo. In: ; CÂmara, José Gomes Bezerra. Trabalhos jurídicos. Rio de Janeiro: Casa de Rui Barbosa, 1962. p. 70.

10. Westel Woodbury Willoughby. The constitutional law of the United States. New York: Nabu Press, 1910. vol. 1. p. 9-10. Vale observar que consolidação do controle de constitucionalidade atribuiu-se à decisão proferida no caso Marbury vs. Madison, em 1803: "Ou a Constituição é a lei superior, intocável por meios ordinários, ou ela está no mesmo nível que os atos legislativos ordinários, e, como os outros atos, é alterável quando à legislatura aprouver altera-los. Se a primeira parte da alternativa é verdadeira, então um ato legislativo contrário à Constituição não é lei; se a última é verdadeira, então as Constituições escritas são tentativas absurdas por parte do povo de limitar um poder por sua própria natureza ilimitável". Afirma ainda Cappelletti que "se é verdadeiro que hoje todas as constituições modernas do mundo ocidental tendem já a afirmar o seu caráter de constituições rígidas e não mais flexíveis, é também verdadeiro, no entanto que este movimento, de importância fundamental e de alcance universal, foi efetivamente, iniciado pela Constituição norte-americana de 1787 e pela corajosa jurisprudência que se aplicou" (Mauro Cappelletti. O controle judicial de constitucionalidade das leis no direito comparado. 2. ed. Porto Alegre: Fabris, 1992. p. 47-48).

11. Para o Prof. Celso Ribeiro Bastos que "toda a norma infringente da Constituição é nula". (Curso de direito constitucional. São Paulo: Celso Bastos Ed., 2002. p. 389). 
eficácia ex tunc e impondo-se o desfazimento no tempo de todos os atos passíveis de retroação que tiverem ocorrido durante a vigência do ato inconstitucional.

Acrescentamos que a CF dispõe que a inconstitucionalidade é reconhecida por decisão declaratória ${ }^{12}$ reforçando a tese da nulidade do ato incons-

Entendem que a norma constitucional é nula: José Cretella Júnior (Elementos de direito constitucional. 4. ed. São Paulo: Ed. RT, 2000. p. 100); Geraldo Ataliba (Regime tributário e Estado de Direito. Disponível em: [www.trf3.jus.br/palestra03.htm]. Acesso em 28.09.2001); Ruy Barbosa. Op. cit., p. 47), Alfredo Buzaid (Da ação direta de declaração de inconstitucionalidade no direito brasileiro. São Paulo: Saraiva, 1958. p. 132), José Afonso da Silva (Curso de direito constitucional positivo. 11. ed. São Paulo: Malheiros, 1996. p. 55), Ada Pellegrini Grinover (Controle da constitucionalidade. Revista Forense. vol. 341. p. 12. Rio de Janeiro: Forense, 1998); Gilmar Ferreira Mendes (Jurisdição constitucional. 2. ed. São Paulo: Saraiva, 1998. p. 256), André Ramos Tavares (Tribunal e jurisdição constitucional. São Paulo: Celso Bastos Ed., 1998. p. 121); Luiz Alberto David Araújo e Vidal Serrano Nunes Júnior (Curso de Direito Constitucional. 4. ed. São Paulo: Saraiva, 2001. p. 25); Michel Temer (Elementos de direito constitucional. 12. ed. São Paulo: Malheiros, 1996. p. 40); José Adércio Leite Sampaio, que fala em nulidade no controle concentrado e inaplicabilidade no incidental ( $A$ constituição reinventada pela jurisdição constitucional. Belo Horizonte: Del Rey, 2002. p. 208); Ives Gandra da Silva Martins e Gilmar Ferreira Mendes (Controle concentrado de constitucionalidade: comentários à Lei n. 9.868, de 10.11.1999. 1. ed. São Paulo: Saraiva, 2001. p. 205-207); Lenio Luiz Streck (Jurisdição constitucional e hermenêutica: uma nova crítica do direito. Porto Alegre: Livraria do Advogado, 2002. p. 541); José Rogério Cruz e Tucci. (Aspectos processuais da denominada ação declaratória de constitucionalidade. In: Martins, Ives Gandra da Silva; Mendes, Gilmar Ferreira (coords.). Ação declaratória de constitucionalidade. São Paulo: Saraiva, 1994. p. 151); Carlos Blanco de Morais, especificamente sobre o direito constitucional brasileiro (Justiça constitucional. Coimbra: Coimbra Ed., 2002. t. I. p 301); e, Juliano Taveira Bernardes (Controle abstrato de constitucionalidade: elementos materiais e princípios processuais. São Paulo: Saraiva, 2004. p. 347). No mesmo sentido é o entendimento do STF: RE 93.173/SP, 2. ${ }^{a}$ T., j. 15.06.1982, rel. Min. Firmino Paz; RE 56.192/ RN, 1. ${ }^{a}$ T., j. 23.03.1965, rel. Min. Cândido Motta; MC na ADIn 1.434/SP, Pleno, j. 29.08.1996, rel. Min. Celso de Mello; QO na ADIn 652/MA, Pleno, j. 02.04.1992, rel. Min. Celso de Mello; Representação 980, j. 21.11.1979, rel. Min. Moreira Alves; RE 103.619, rel. Min. Oscar Corrêa, RDA 160/80 e s.; RTJ 55/744, 87/758, 89/367, 95/993 e 101/503.

12. Aplicável à lição de Carlos Maximiliano: "interpretem-se as disposições de modo que não pareça haver palavras supérfluas e sem força operativa" (Hermenêutica e aplicação do direito. 7. ed. São Paulo: Livraria Freitas Bastos, 1961. p. 312). 
titucional, já que as decisões declaratórias ${ }^{13}$ reconhecem atos nulos, ${ }^{14}$ não anuláveis. ${ }^{15}$

Verificada a premissa inicial no sentido da adoção da sanção nulidade pela doutrina e jurisprudência do STF, resta abordar o reconhecimento por este E. Tribunal da inconstitucionalidade de leis estaduais pela ausência da Lei Complementar exigida pelo art. $18, \S 4 .^{\circ}$, da CF/1988, bem como da omissão do legislador.

\section{InCONSTITUCIONALIDADE POR VIOLAÇãO AO ART. $18, \S 4 .{ }^{\circ}$, DA CF/1988}

Consoante afirmamos na introdução, com a EC 15, de $12.09 .1996,{ }^{16} \mathrm{o}$ art. $18, \S 4 .^{\circ}$, da CF/1988, passou a determinar que "a criação, a incorporação, a

13. Como leciona Antonio Carlos de Araújo Cintra, Ada Pellegrini Grinover, e Cândido Rangel Dinamarco "o processo meramente declaratório visa apenas à declaração da existência ou inexistência da relação jurídica". (Teoria geral do processo. 10. ed. São Paulo: Malheiros, 1994. p. 302). Entendemos que é aplicável o conceito acima aos processos de controle abstrato, já que a inconstitucionalidade é uma relação jurídica.

14. Canotilho aponta: "Fala-se em efeito declarativo quando a entidade controlante se limita a declarar a nulidade pré-existente do acto normativo. O acto normativo é absolutamente nulo (null and void) e, por isso, o juiz ou qualquer outro órgão de controlo 'limita-se' a reconhecer declarativamente a sua nulidade. É o regime típico do controle difuso" (José Joaquim Gomes Canotilho. Direito constitucional. 6. ed. Almedina: Coimbra, 1993. p. 875).

15. Sobre o tema vide a obra Controle de constitucionalidade e seus efeitos de Olavo Augusto Vianna Alves Ferreira. (2. ed. São Paulo: Método, 2005), E ainda, Walber de Moura Agra afirma que em alguns casos a decisão de inconstitucionalidade é constitutiva negativa, "tornando-se o ato inconstitucional por vontade do Poder Judiciário, dimensionando-se o STF como um órgão legislativo negativo" (Curso de direito constitucional. Rio de Janeiro: Forense, 2006. p. 495).

16. Vale observar que a EC 15 veio após crescente proliferação de Municípios ocorrida no período posterior a 1988, alterando as condições propícias para que os Estados desencadeassem o processo de criação, fusão, incorporação e desmembramento de Municípios, por leis próprias, respeitados parâmetros mínimos definidos em lei complementar, também estadual, prevista na redação original do art. $18, \S 4 .^{\circ}$, da CF/1988. A Justificação apresentada na PEC 22/1996, no Senado Federal, esclarece os motivos da mudança constitucional (f. 55): "O aparecimento de um número elevado de municípios novos, no País, tem chamado atenção para o caráter essencialmente eleitoreiro que envolve suas criações, fato este lamentável. Ao determinar a responsabilidade da criação de municípios aos Estados, a Constituição Federal considerou corretamente as particularidades regionais a que devem obedecer os requisitos para a criação de municípios. Contudo, o texto do $\S 4 .^{\circ}$ do art. 18 não apresentou as restri- 
fusão e o desmembramento de Municípios, far-se-ão por lei estadual, dentro do período determinado por Lei Complementar federal, e dependerão de consulta prévia, mediante plebiscito, às populações dos Municípios envolvidos, após divulgação dos Estudos de Viabilidade Municipal, apresentados e publicados na forma da lei".

Passados mais de 13 anos da publicação da EC 15, não foi editada a Lei Complementar federal regulamentando o período dentro do qual poderão tramitar os procedimentos tendentes à criação, incorporação, desmembramento e fusão de Municípios.

Como norma de eficácia limitada,${ }^{17}$ o art. 18, \& 4..$^{\circ}$, da CF/1988, com a redação determinada pela EC 15, para produzir plenos efeitos depende da atuação legislativa no sentido da feitura da referida Lei Complementar, sem a qual é inviável a instauração de processos tendentes à criação, à incorporação, à fusão e ao desmembramento de municipalidades. ${ }^{18}$

ções necessárias ao consentimento dos abusos, hoje observado, e que não levam em conta os aspectos mais relevantes para a criação ou não de novos municípios. A determinação, no mesmo parágrafo, de que ficarão preservadas a continuidade e a unidade histórico-cultural do ambiente urbano deixa muito a desejar, por constituir uma condição nem precisa, nem objetiva. Aceitamos que, para dispor mais objetivamente sobre a questão, a Constituição Federal deveria ser mais incisiva na determinação de condições capazes de evitar, ao máximo, distorções que ameacem a transparência e o amadurecimento da decisão técnica e política. Assim, nesta proposta de emenda à Constituição, estamos incluindo dois elementos, a nosso ver, muito importantes. Primeiro, o período em que poderão ser criados os municípios, que deverá ser limitado com relação à época das eleições municipais. Este período será determinado por lei complementar federal. Segundo, a apresentação e publicação, na forma da lei, dos Estudos de Viabilidade Municipal, os quais deverão dar o necessário embasamento, sob diferentes perspectivas, à decisão da população, manifesta em plebiscito" (ADIn 3.682/MT, rel. Min. Gilmar Mendes, DJ 06.09.2007).

17. No mesmo sentido: José Afonso da Silva. Aplicabilidade das normas constitucionais. 6. ed. São Paulo: Malheiros, 2003.

18. "Em parecer rigoroso e analítico, o Procurador-Geral da República, Dr. Antonio Fernando Barros e Silva de Souza, após estudar as condições em que inatividade do legislador configura a omissão inconstitucional, assim analisa o presente caso: (...) Observemos ainda que o silêncio do legislador federal termina por comprometer a autonomia das entidades federativas estaduais e municipais, incapacitadas que ficam de organizar adequada e convenientemente a distribuição do poder político-administrativo nos respectivos territórios. 25. O federalismo se diferencia das outras formas de estado exatamente por garantir, por meio da Constituição, esferas de autoconformação, inclusive territorial, aos entes federados. O Brasil, como sabemos, é um fede- 
Ocorre que, dentro deste grande lapso de tempo (13 anos), Municípios foram criados, "eleições realizadas, poderes municipais devidamente estruturados, tributos municipais recolhidos, domicílios fixados para todos os efeitos da lei etc.; enfim, toda uma realidade fática e jurídica criada sem qualquer base legal ou constitucional". ${ }^{19}$

Assim, por não ter sido editada a Lei Complementar federal exigida pelo art. 18, § 4. ${ }^{\circ}$, da CF/1988, o Tribunal aplicou a modulação da declaração de inconstitucionalidade pelo prazo de 24 meses:

a) na ADIn 2.240/BA, ${ }^{20}$ proposta pelo Partido dos Trabalhadores, ao declarar a inconstitucionalidade da Lei estadual 7.619, de 30.03.2000, que criou o

ralismo tripartite ou de três níveis, assim como a Bélgica, embora, evidentemente, sob outras razões, por ter destacado os municípios como partes disjuntivas da federação. 26. Pois bem, a lei complementar federal ainda por fazer-se é imprescindível para que se adotem todas as providências necessárias à criação de municipalidades que demonstrem viabilidade econômico-financeira e o desejo da população em emancipar-se" (ADIn 3.682/MT, rel. Min. Gilmar Mendes, DJ 06.09.2007).

19. Voto do Min. Gilmar Mendes na ADIn 3.682/MT (rel. Min. Gilmar Mendes, DJ 06.09.2007).

20. Ementa: "Ação direta de inconstitucionalidade. Lei 7.619/2000, do Estado da Bahia, que criou o município de Luís Eduardo Magalhães. Inconstitucionalidade de lei estadual posterior à EC 15/1996. Ausência de Lei Complementar federal prevista no texto constitucional. Afronta ao disposto no art. 18, § 4. ${ }^{\circ}$, da Constituição do Brasil. Omissão do Poder Legislativo. Existência de fato. Situação consolidada. Princípio da segurança da jurídica. Situação de exceção, estado de exceção. A exceção não se subtrai à norma, mas esta, suspendendo-se, dá lugar à exceção - apenas assim ela se constitui como regra, mantendo-se em relação com a exceção. 1. O Município foi efetivamente criado e assumiu existência de fato, há mais de seis anos, como ente federativo. 2. Existência de fato do Município, decorrente da decisão política que importou na sua instalação como ente federativo dotado de autonomia.

Situação excepcional consolidada, de caráter institucional, político. Hipótese que consubstancia reconhecimento e acolhimento da força normativa dos fatos. 3. Esta Corte não pode limitar-se à prática de mero exercício de subsunção. A situação de exceção, situação consolidada - embora ainda não jurídica - não pode ser desconsiderada. 4. A exceção resulta de omissão do Poder Legislativo, visto que o impedimento de criação, incorporação, fusão e desmembramento de Municípios, desde a promulgação da EC 15, em 12.09.1996, deve-se à ausência de Lei Complementar federal. 5. Omissão do Congresso Nacional que inviabiliza o que a Constituição autoriza: a criação de Município. A não edição da Lei Complementar dentro de um prazo razoável consubstancia autêntica violação da ordem constitucional. 6. A criação do Município de Luís Eduardo Magalhães importa, tal como se deu, uma situação excepcional não prevista pelo direito positivo. 7. O estado de exceção é uma zona de indiferença entre 
Município de Luís Eduardo Magalhães, desmembrado do Município de Barreiras;

b) na ADIn 3.316/MT, ${ }^{21}$ proposta pelo Procurador-Geral da República, ao declarar a inconstitucionalidade da Lei estadual 6.983/1998, que criou o Mu-

o caos e o estado da normalidade. Não é a exceção que se subtrai à norma, mas a norma que, suspendendo-se, dá lugar à exceção - apenas desse modo ela se constitui como regra, mantendo-se em relação com a exceção. 8. Ao STF incumbe decidir regulando também essas situações de exceção. Não se afasta do ordenamento, ao fazê-lo, eis que aplica a norma à exceção desaplicando-a, isto é, retirando-a da exceção. 9. Cumpre verificar o que menos compromete a força normativa futura da Constituição e sua função de estabilização. No aparente conflito de inconstitucionalidades impor-se-ia o reconhecimento da existência válida do Município, a fim de que se afaste a agressão à federação. 10. O princípio da segurança jurídica prospera em benefício da preservação do Município. 11. Princípio da continuidade do Estado. 12. Julgamento no qual foi considerada a decisão desta Corte no MI 725, quando determinado que o Congresso Nacional, no prazo de dezoito meses, ao editar a lei complementar federal referida no \& 4. ${ }^{\circ}$ do art. 18 da Constituição do Brasil, considere, reconhecendo-a, a existência consolidada do Município de Luís Eduardo Magalhães. Declaração de inconstitucionalidade da lei estadual sem pronúncia de sua nulidade 13. Ação direta julgada procedente para declarar a inconstitucionalidade, mas não pronunciar a nulidade pelo prazo de 24 meses, da Lei 7.619, de 30.03.2000, do Estado da Bahia" (ADIn 2.240/BA, rel. Min. Eros Grau, DJ 03.08.2007).

21. Ementa: "Ação direta de inconstitucionalidade. Lei 6.893, de 28.01.1998, do Estado do Mato Grosso, que criou o Município de Santo Antônio do Leste. Inconstitucionalidade de lei estadual posterior à EC 15/1996. Ausência de Lei Complementar federal prevista no texto constitucional. afronta ao disposto no art. $18, \S 4 .^{\circ}$, da Constituição do Brasil. Omissão do Poder Legislativo. Existência de fato. Situação consolidada. Princípio da segurança da jurídica. Situação de exceção, estado de exceção. A exceção não se subtrai à norma, mas esta, suspendendo-se, dá lugar à exceção - apenas assim ela se constitui como regra, mantendo-se em relação com a exceção. 1. O Município foi efetivamente criado e assumiu existência de fato, como ente federativo. 2. Existência de fato do Município, decorrente da decisão política que importou na sua instalação como ente federativo dotado de autonomia. Situação excepcional consolidada, de caráter institucional, político. Hipótese que consubstancia reconhecimento e acolhimento da força normativa dos fatos. 3. Esta Corte não pode limitar-se à prática de mero exercício de subsunção. A situação de exceção, situação consolidada - embora ainda não jurídica - não pode ser desconsiderada. 4. A exceção resulta de omissão do Poder Legislativo, visto que o impedimento de criação, incorporação, fusão e desmembramento de Municípios, desde a promulgação da EC 15, em 12.09.1996, deve-se à ausência de Lei Complementar federal. 5. Omissão do Congresso Nacional que inviabiliza o que a Constituição autoriza: a criação de Município. A não edição da lei complementar dentro de um prazo razoável consubstancia autêntica violação da ordem constitucional. 6. A criação do Município de Santo Antônio do Leste importa, 
nicípio de Santo Antônio do Leste, com área territorial desmembrada do Município de Novo São Joaquim;

c) na ADIn 3.489/SC, ${ }^{22}$ proposta pelo Procurador-Geral da República, ao declarar a inconstitucionalidade da Lei estadual 12.294, de 22.06.2002, que

tal como se deu, uma situação excepcional não prevista pelo direito positivo. 7. O estado de exceção é uma zona de indiferença entre o caos e o estado da normalidade. Não é a exceção que se subtrai à norma, mas a norma que, suspendendo-se, dá lugar à exceção - apenas desse modo ela se constitui como regra, mantendo-se em relação com a exceção. 8. Ao STF incumbe decidir regulando também essas situações de exceção. Não se afasta do ordenamento, ao fazê-lo, eis que aplica a norma à exceção desaplicando-a, isto é, retirando-a da exceção. 9. Cumpre verificar o que menos compromete a força normativa futura da Constituição e sua função de estabilização. No aparente conflito de inconstitucionalidades impor-se-ia o reconhecimento da existência válida do Município, a fim de que se afaste a agressão à federação. 10 . O princípio da segurança jurídica prospera em benefício da preservação do Município. 11. Princípio da continuidade do Estado. 12. Julgamento no qual foi considerada a decisão desta Corte no MI n. 725, quando determinado que o Congresso Nacional, no prazo de dezoito meses, ao editar a lei complementar federal referida no $\S 4 .^{\circ}$ do art. 18 da Constituição do Brasil, considere, reconhecendo-a, a existência consolidada do Município de Luís Eduardo Magalhães. Declaração de inconstitucionalidade da lei estadual sem pronúncia de sua nulidade" (ADIn 3.316/MT, rel. Min. Eros Grau, DJ 29.06.2007).

22. Ementa: "Ação direta de inconstitucionalidade. Lei 12.294, de 22.06.2002, do Estado de Santa Catarina, que anexou a localidade de Vila Arlete, desmembrada do Município de Campos Novos, ao Município de Monte Carlo. Inconstitucionalidade de lei estadual posterior à EC 15/1996. Ausência de Lei Complementar federal prevista no texto constitucional. Afronta ao disposto no art. 18, § 4. ${ }^{\circ}$, da Constituição do Brasil. Omissão do Poder Legislativo. Existência de fato. Situação consolidada. Princípio da segurança da jurídica. Situação de exceção, estado de exceção. A exceção não se subtrai à norma, mas esta, suspendendo-se, dá lugar à exceção - apenas assim ela se constitui como regra, mantendo-se em relação com a exceção. 1. A localidade de Vila Arlete, desmembrada do Município de Campos Novos, foi efetivamente integrada ao Município de Monte Carlo. 2. Existência de fato da agregação da faixa de terra ao Município de Monte Carlo, decorrente da decisão política que importou na sua instalação como ente federativo dotado de autonomia. Situação excepcional consolidada, de caráter institucional, político. Hipótese que consubstancia reconhecimento e acolhimento da força normativa dos fatos. 3. Esta Corte não pode limitar-se à prática de mero exercício de subsunção. A situação de exceção, situação consolidada - embora ainda não jurídica - não pode ser desconsiderada. 4. A exceção resulta de omissão do Poder Legislativo, visto que o impedimento de criação, incorporação, fusão e desmembramento de Municípios, desde a promulgação da EC 15, em 12.09.1996, deve-se à ausência de Lei Complementar federal. 5. Omissão do Congresso Nacional que inviabiliza o que a Constituição autoriza: o desmembramento de parte de Município 
anexou ao Município e Montes Claros a localidade Vila Arlete, desmembrada do Município de Campos Novos; e,

d) na ADIn 3.689/PA, ${ }^{23}$ proposta pelo Partido do Movimento Democrático Brasileiro (PMDB), ao declarar a inconstitucionalidade da Lei 6.066, de

e sua consequente adição a outro. A não edição da Lei Complementar dentro de um prazo razoável consubstancia autêntica violação da ordem constitucional. 6. O desmembramento e integração da localidade de Vila Arlete objeto da lei importa, tal como se deu, uma situação excepcional não prevista pelo direito positivo. 7. O estado de exceção é uma zona de indiferença entre o caos e o estado da normalidade. Não é a exceção que se subtrai à norma, mas a norma que, suspendendo-se, dá lugar à exceção - apenas desse modo ela se constitui como regra, mantendo-se em relação com a exceção. 8. Ao STF incumbe decidir regulando também essas situações de exceção. Não se afasta do ordenamento, ao fazê-lo, eis que aplica a norma à exceção desaplicando-a, isto é, retirando-a da exceção. 9. Cumpre verificar o que menos compromete a força normativa futura da Constituição e sua função de estabilização. No aparente conflito de inconstitucionalidades impor-se-ia o reconhecimento do desmembramento de gleba de um Município e sua integração a outro, a fim de que se afaste a agressão à federação. 10. O princípio da segurança jurídica prospera em benefício da preservação do Município. 11. Princípio da continuidade do Estado. 12. Julgamento no qual foi considerada a decisão desta Corte no MI 725, quando determinado que o Congresso Nacional, no prazo de 18 meses, ao editar a Lei Complementar federal referida no $\S 4 .^{\circ}$ do art. 18 da Constituição do Brasil, considere, reconhecendo-a, a existência consolidada do Município de Luís Eduardo Magalhães. Declaração de inconstitucionalidade da lei estadual sem pronúncia de sua nulidade" (ADIn 3.489/SC, rel. Min. Eros Grau, DJ 03.08.2007).

23. Ementa: "Ação direta de inconstitucionalidade. Lei 6.066, do Estado do Pará, que alterando divisas, desmembrou faixa de terra do Município de Água Azul do Norte e integrou-a ao Município de Ourilândia do Norte. inconstitucionalidade de lei estadual posterior à EC 15/1996. ausência de Lei Complementar federal prevista no texto constitucional. afronta ao disposto no art. 18, § 4. ${ }^{\circ}$, da Constituição do Brasil. Omissão do Poder Legislativo. Existência de fato. Situação consolidada. Princípio da segurança da jurídica. Situação de exceção, estado de exceção. A exceção não se subtrai à norma, mas esta, suspendendo-se, dá lugar à exceção - apenas assim ela se constitui como regra, mantendo-se em relação com a exceção. 1. A fração do Município de Água Azul do Norte foi integrada ao Município de Ourilândia do Norte apenas formalmente pela Lei estadual 6.066, vez que materialmente já era esse o município ao qual provia as necessidades essenciais da população residente na gleba desmembrada. Essa fração territorial fora já efetivamente agregada, assumindo existência de fato como parte do ente federativo - Município de Ourilândia do Norte. Há mais de nove anos. 2. Existência de fato da agregação da faixa de terra ao Município de Ourilândia do Norte, decorrente da decisão política que importou na sua instalação como ente federativo dotado de autonomia. Situação excepcional consolidada, de caráter 
14.08.1997, que alterou os limites entre os Municípios de Ourilândia do Norte e Água Azul do Norte.

Também por não ter sido editada a lei complementar federal exigida pelo art. 18 , \& 4..$^{\circ}$, da CF/1988, o STF, por unanimidade, julgou procedente pedido formulado na ADIn por omissão 3.682/MT, ${ }^{24}$ ajuizada pela Assembleia Legis-

institucional, político. Hipótese que consubstancia reconhecimento e acolhimento da força normativa dos fatos. 3. Esta Corte não pode limitar-se à prática de mero exercício de subsunção. A situação de exceção, situação consolidada - embora ainda não jurídica - não pode ser desconsiderada. 4. A exceção resulta de omissão do Poder Legislativo, visto que o impedimento de criação, incorporação, fusão e desmembramento de Municípios, desde a promulgação da EC 15, em 12.09.1996, deve-se à ausência de Lei Complementar federal. 5. Omissão do Congresso Nacional que inviabiliza o que a Constituição autoriza: o desmembramento de parte de Município e sua consequente adição a outro. A não edição da lei complementar dentro de um prazo razoável consubstancia autêntica violação da ordem constitucional. 6. A integração da gleba objeto da lei importa, tal como se deu, uma situação excepcional não prevista pelo direito positivo. 7. O estado de exceção é uma zona de indiferença entre o caos e o estado da normalidade. Não é a exceção que se subtrai à norma, mas a norma que, suspendendo-se, dá lugar à exceção - apenas desse modo ela se constitui como regra, mantendo-se em relação com a exceção. 8. Ao STF incumbe decidir regulando também essas situações de exceção. Não se afasta do ordenamento, ao fazê-lo, eis que aplica a norma à exceção desaplicando-a, isto é, retirando-a da exceção. 9. Cumpre verificar o que menos compromete a força normativa futura da Constituição e sua função de estabilização. No aparente conflito de inconstitucionalidades impor-se-ia o reconhecimento do desmembramento de gleba de um Município e sua integração a outro, a fim de que se afaste a agressão à federação. 10. O princípio da segurança jurídica prospera em benefício da preservação do Município. 11. Princípio da continuidade do Estado. 12. Julgamento no qual foi considerada a decisão desta Corte no MI 725, quando determinado que o Congresso Nacional, no prazo de dezoito meses, ao editar a Lei Complementar federal referida no $\S 4 .^{\circ}$ do art. 18 da Constituição do Brasil, considere, reconhecendo-a, a existência consolidada do Município de Luís Eduardo Magalhães. Declaração de inconstitucionalidade da lei estadual sem pronúncia de sua nulidade inconstitucionalidade, mas não pronunciar a nulidade pelo prazo de 24 meses, da Lei 6.066, de 14.08.1997, do Estado do Pará" (ADIn 3.689/PA, rel. Min. Eros Grau, DJ 26.09.2008).

24. Ementa: "Ação direta de inconstitucionalidade por omissão. Inatividade do legislador quanto ao dever de elaborar a Lei Complementar a que se refere o $\S 4 .^{\circ}$ do art. 18 da CF/1988, na redação dada pela EC 15/1996. Ação julgada procedente. 1. A EC 15, que alterou a redação do $\S 4 .^{\circ}$ do art. 18 da CF/1988, foi publicada no dia 13.09.1996. Passados mais de 10 anos, não foi editada a Lei Complementar federal definidora do período dentro do qual poderão tramitar os procedimentos tendentes à criação, 
lativa do Estado, para reconhecer a mora do Congresso Nacional. Por maioria, estabeleceu o prazo de 18 meses para que este adote todas as providências legislativas ao cumprimento da referida norma constitucional.

Neste contexto, optou o Congresso Nacional por editar a EC 57, que pretendeu convalidar os atos inconstitucionais por ausência da lei complementar exigida pelo art. $18, \S 4 .^{\circ}$, da $\mathrm{CF} / 1988$, como veremos a seguir.

\section{A EC 57 E A CONVALIDAÇÃO DA DECLARAÇÃO DE INCONSTITUCIONALIDADE}

Não obstante o reconhecimento da inconstitucionalidade de leis estaduais afrontando o requisito previsto no art. $18, \S 4^{\circ}{ }^{\circ}$, da $\mathrm{CF} / 1988$, qual seja, por ausência da Lei Complementar, e patente a inconstitucionalidade por omissão do Legislativo Nacional, foi edita a EC 57, de 18.12.2008, nos seguintes termos:

"Art. 1. ${ }^{\circ} \mathrm{O}$ Ato das Disposições Constitucionais Transitórias passa a vigorar acrescido do seguinte art. 96:

incorporação, desmembramento e fusão de municípios. Existência de notório lapso temporal a demonstrar a inatividade do legislador em relação ao cumprimento de inequívoco dever constitucional de legislar, decorrente do comando do art. 18, § 4. ${ }^{\circ}$, da CF/1988. 2. Apesar de existirem no Congresso Nacional diversos projetos de lei apresentados visando à regulamentação do art. 18, \& 4..$^{\circ}$, da $\mathrm{CF} / 1988$, é possível constatar a omissão inconstitucional quanto à efetiva deliberação e aprovação da Lei Complementar em referência. As peculiaridades da atividade parlamentar que afetam, inexoravelmente, o processo legislativo, não justificam uma conduta manifestamente negligente ou desidiosa das Casas Legislativas, conduta esta que pode pôr em risco a própria ordem constitucional. A inertia deliberandi das Casas Legislativas pode ser objeto da ação direta de inconstitucionalidade por omissão. 3. A omissão legislativa em relação à regulamentação do art. $18, \S 4 .^{\circ}$, da CF/1988, acabou dando ensejo à conformação e à consolidação de estados de inconstitucionalidade que não podem ser ignorados pelo legislador na elaboração da Lei Complementar federal. 4. Ação julgada procedente para declarar o estado de mora em que se encontra o Congresso Nacional, a fim de que, em prazo razoável de 18 meses, adote ele todas as providências legislativas necessárias ao cumprimento do dever constitucional imposto pelo art. 18, $\S 4 .^{\circ}$, da CF/1988, devendo ser contempladas as situações imperfeitas decorrentes do estado de inconstitucionalidade gerado pela omissão. Não se trata de impor um prazo para a atuação legislativa do Congresso Nacional, mas apenas da fixação de um parâmetro temporal razoável, tendo em vista o prazo de 24 meses determinado pelo Tribunal nas Ações Diretas de Inconstitucionalidade 2.240/BA, 3.316/MT, 3.489/SC e 3.689/PA, para que as leis estaduais que criam municípios ou alteram seus limites territoriais continuem vigendo, até que a lei complementar federal seja promulgada contemplando as realidades desses municípios" (ADIn 3.682/MT, rel. Min. Gilmar Mendes, DJ 06.09.2007). 
'Art. 96. Ficam convalidados os atos de criação, fusão, incorporação e desmembramento de Municípios, cuja lei tenha sido publicada até 31 de dezembro de 2006, atendidos os requisitos estabelecidos na legislação do respectivo Estado à época de sua criação'.

Art. 2. ${ }^{\circ}$ Esta Emenda Constitucional entra em vigor na data de sua publicação."

Surgem, então, as questões: o ato inconstitucional é passível de convalidação? O Legislativo possui competência para perpetuar os efeitos do ato declarado inconstitucional pelo STF?

Dividimos o estudo destas questões em dois subitens. No primeiro será abordada a convalidação do ato inconstitucional e, no segundo, a competência do Legislativo para perpetuar os efeitos do ato declarado inconstitucional pelo STF.

\subsection{A convalidação do ato inconstitucional}

Tendo em vista a adoção do princípio da nulidade do ato inconstitucional, ${ }^{25}$ segundo o qual a declaração de inconstitucionalidade possui eficácia ex tunc, impondo-se o desfazimento no tempo de todos os atos passíveis de retroação que tiverem ocorrido durante a vigência do ato inconstitucional, ainda que excepcionalmente seus efeitos concretos possam ser mantidos pelo instituto da modulação, ${ }^{26}$ o sistema jurídico brasileiro não contempla a figura da constitucionalidade superveniente ou da convalidação do ato inconstitucional.

Dessa maneira, conforme entendimento do Pretório Excelso, ${ }^{27}$ a superveniência de Emenda à Constituição, derivada do exercício do poder de reforma pelo

25. Ver item 1 (O princípio da nulidade do ato inconstitucional) do presente trabalho.

26. As Leis 9.868/1999 e 9.882/1999, por meio dos seus arts. 27 e 11, respectivamente, estabelecem que: "Ao declarar a inconstitucionalidade de lei ou ato normativo, e tendo em vista razões de segurança jurídica ou de excepcional interesse social, poderá o Supremo Tribunal Federal, por maioria de 2/3 (dois terços) de seus membros, restringir os efeitos daquela declaração ou decidir que ela só tenha eficácia a partir de seu trânsito em julgado ou de outro momento que venha a ser fixado". Eis o instituto da modulação temporal dos efeitos no controle de constitucionalidade, objeto de nosso trabalho.

27. STF: "Constitucionalidade superveniente-Art. $3 .^{\circ}, \S 1 .^{\circ}$, da Lei 9.718, de 27.11.1998 - EC 20, de 15.12.1998. O sistema jurídico brasileiro não contempla a figura da constitucionalidade superveniente" (RE 346.084, Pleno, j. 09.11.2005, rel. Min. Ilmar Galvão, rel. p/ acórdão Min. Marco Aurélio, DJ 01.09.2006). No precitado julgado o 
Min.Celso de Mello sintetiza: "Se o Poder Público quiser proceder de acordo com o teor de superveniente emenda à Constituição, deverá produzir nova legislação compatível com o conteúdo resultante do processo de reforma constitucional, não se viabilizando, em consequência, a convalidação de diploma legislativo originariamente inconstitucional (...) Cumpre advertir, por isso mesmo, que a superveniência de emenda à Constituição, derivada do exercício, pelo Congresso Nacional, do poder de reforma, não tem o condão de validar legislação comum anterior, até então compatível com o modelo positivado no texto da Carta Política" (grifo nosso). Da mesma maneira, entendeu o STF em julgado recente: "Ação direta de inconstitucionalidade. AMB. Lei 12.398/1998 do Paraná. Decreto estadual 721/1999. Edição da EC 41/2003. Substancial alteração do parâmetro de controle. Não ocorrência de prejuízo. Superação da jurisprudência da Corte acerca da matéria. Contribuição dos inativos. Inconstitucionalidade sob a EC 20/1998. Precedentes. 1. Em nosso ordenamento jurídico, não se admite a figura da constitucionalidade superveniente. Mais relevante do que a atualidade do parâmetro de controle é a constatação de que a inconstitucionalidade persiste e é atual, ainda que se refira a dispositivos da Constituição Federal que não se encontram mais em vigor. Caso contrário, ficaria sensivelmente enfraquecida a própria regra que proíbe a convalidação. 2. A jurisdição constitucional brasileira não deve deixar às instâncias ordinárias a solução de problemas que podem, de maneira mais eficiente, eficaz e segura, ser resolvidos em sede de controle concentrado de normas. 3. A Lei estadual 12.398/1998, que criou a contribuição dos inativos no Estado do Paraná, por ser inconstitucional ao tempo de sua edição, não poderia ser convalidada pela EC 41/2003. E, se a norma não foi convalidada, isso significa que a sua inconstitucionalidade persiste e é atual, ainda que se refira a dispositivos da Constituição Federal que não se encontram mais em vigor, alterados que foram pela EC 41/2003. Superada a preliminar de prejudicialidade da ação, fixando o entendimento de, analisada a situação concreta, não se assentar o prejuízo das ações em curso, para evitar situações em que uma lei que nasceu claramente inconstitucional volte a produzir, em tese, seus efeitos, uma vez revogada as medidas cautelares concedidas já há dez anos. 4. No mérito, é pacífica a jurisprudência desta Corte no sentido de que é inconstitucional a incidência, sob a égide da EC 20/1998, de contribuição previdenciária sobre os proventos dos servidores públicos inativos e dos pensionistas, como previu a Lei 12.398/1998, do Estado do Paraná (cf. MC na ADIn 2.010/DF, rel. o Min. Celso de Mello, DJ 12.04.2002; e AgRg no RE 408.824/RS, 2. ${ }^{a}$ T., rel. o Min. Eros Grau, DJ 25.04.2008). 5. É igualmente inconstitucional a incidência, sobre os proventos de inativos e pensionistas, de contribuição compulsória para o custeio de serviços médico-hospitalares (cf. AgRg no RE 346.797/RS, rel. o Min. Joaquim Barbosa, 1. ${ }^{a}$ T., DJ 28.11.2003; MC na ADIn 1.920/BA, rel. Min. Nelson Jobim, DJ 20.09.2002). 6. Declaração de inconstitucionalidade por arrastamento das normas impugnadas do decreto regulamentar, em virtude da relação de dependência com a lei impugnada. Precedentes. 7. Ação direta de inconstitucionalidade julgada parcialmente procedente" (ADIn 2.158/PR, Pleno, j. 15.09.2010, rel. Min. Dias Toffoli, DJ 
16.12.2010). No STF no sentido da ausência de convalidação do ato inconstitucional: "Ementa: Ação direta de inconstitucionalidade - Promoção de praças da polícia militar e do corpo de bombeiros - Regime jurídico dos servidores públicos - Processo legislativo - Instauração dependente de iniciativa constitucionalmente reservada ao chefe do Poder Executivo - Diploma legislativo estadual que resultou de iniciativa parlamentar - Usurpação do poder de iniciativa - Sanção tácita do projeto de lei Irrelevância - Insubsistência da Súmula 5/STF - Inconstitucionalidade formal - Eficácia repristinatória da declaração de inconstitucionalidade proferida pelo STF em sede de controle normativo abstrato - Ação direta julgada procedente. Os princípios que regem o processo legislativo impõem-se à observância dos Estados-membros - O modelo estruturador do processo legislativo, tal como delineado em seus aspectos fundamentais pela Constituição da República, impõe-se, enquanto padrão normativo de compulsório atendimento, à observância incondicional dos Estados-membros. Precedentes - A usurpação do poder de instauração do processo legislativo em matéria constitucionalmente reservada à iniciativa de outros órgãos e agentes estatais configura transgressão ao texto da Constituição da República e gera, em consequência, a inconstitucionalidade formal da lei assim editada. Precedentes. A sanção do projeto de lei não convalida o vício de inconstitucionalidade resultante da usurpação do poder de iniciativa - A ulterior aquiescência do Chefe do Poder Executivo, mediante sanção do projeto de lei, ainda quando dele seja a prerrogativa usurpada, não tem o condão de sanar o vício radical da inconstitucionalidade. Insubsistência da Súmula 5/STF. Doutrina. Precedentes. Significação constitucional do regime jurídico dos servidores públicos (civis e militares) - A locução constitucional 'regime jurídico dos servidores públicos' corresponde ao conjunto de normas que disciplinam os diversos aspectos das relações, estatutárias ou contratuais, mantidas pelo Estado com os seus agentes. Precedentes. A questão da eficácia repristinatória da declaração de inconstitucionalidade in abstracto - A declaração final de inconstitucionalidade, quando proferida pelo STF em sede de fiscalização normativa abstrata, importa - considerado o efeito repristinatório que lhe é inerente - em restauração das normas estatais anteriormente revogadas pelo diploma normativo objeto do juízo de inconstitucionalidade, eis que o ato inconstitucional, por ser juridicamente inválido (RTJ 146/461-462), sequer possui eficácia derrogatória. Doutrina. Precedentes" (STF, ADIn 2867/ES, Pleno, j. 03.12.2003, rel. Min. Celso de Mello, DJ 09.02.2007); e "Ementa: Regime jurídico dos servidores públicos estaduais. Aposentadoria e vantagens financeiras. Inconstitucionalidade formal. Vício que persiste, não obstante a sanção do respectivo projeto de lei. Precedentes. 1. Dispositivo legal oriundo de emenda parlamentar referente aos servidores públicos estaduais, sua aposentadoria e vantagens financeiras. Inconstitucionalidade formal em face do disposto no art. $61, \S 1 .^{\circ}$, II, $c$, da Carta Federal. 2. É firme na jurisprudência do Tribunal que a sanção do projeto de lei não convalida o defeito de iniciativa. Precedentes. Procedência da ação. Inconstitucionalidade da Lei 1.786, de 09.01.1991, do Estado do Rio de Janeiro" (STF, ADIn 700/RJ, Pleno, j. 23.05.2001, rel. Min. Maurício Corrêa, DJ 24.08.2001). 
Legislativo (limitado materialmente), não tem o condão de convalidar legislação inconstitucional anterior, sob pena de violação dos princípios da nulidade do ato inconstitucional, da supremacia da Constituição e da segurança jurídica. ${ }^{28}$

Assim, a EC 57, ao pretender convalidar os atos inconstitucionais (por ausência da Lei Complementar exigida pelo art. 18, § 4. ${ }^{\circ}$, da CF/1988), afronta os princípios da separação de funções, nulidade do ato inconstitucional, da supremacia da Constituição e da segurança jurídica, verdadeiras vigas mestras do ordenamento pátrio.

\subsection{Competência do Legislativo para perpetuar os efeitos do ato declarado inconstitucional pelo STF?}

Impende lembrar que o STF no julgamento da ADIn por omissão 3.682/ MT, ${ }^{29}$ concedeu prazo de 18 meses para que o Congresso adotasse todas as providências legislativas tendentes ao cumprimento do art. 18, § 4. ${ }^{\circ}$, da CF/1988. Ao proferir seu voto neste julgamento, o Min. Gilmar Mendes reconheceu o caráter nitidamente mandamental da respectiva sentença, "que impõe ao legislador em mora o dever, dentro de um prazo razoável, de proceder à eliminação do estado de inconstitucionalidade". ${ }^{30}$ Afirmou ainda que o "dever dos Poderes Constitucionais ou dos órgãos administrativos de proceder à imediata eliminação do estado de inconstitucionalidade parece ser uma das consequências menos controvertidas da decisão que porventura venha a declarar a inconstitucionalidade de uma omissão que afete a efetividade de norma constitucional". ${ }^{31}$

Também, ao declarar a inconstitucionalidade das leis estaduais nas ADIn 3.489/SC e. 3.689/PA, modulou os efeitos de sua declaração por 24 meses "para que as leis estaduais que criam Municípios ou alteram seus limites territoriais continuem vigendo, até que a Lei Complementar federal seja promulgada contemplando as realidades desses Municípios". 32

Vale observar que, caso fosse editada a Lei Complementar em comento, esta retroagiria, ${ }^{33}$ tornando sem efeito a discussão ora deduzida, já que, neste caso,

28. José Carlos Francisco. Convalidação de norma inconstitucional e constitucionalidade superveniente - Impossibilidade. Disponível em: [www.ibec.inf.br/jose.pdf]. Acesso em: 14.07.2010.

29. STF, ADIn 3.682/MT, rel. Min. Gilmar Mendes, DJ 06.09.2007.

30. Idem.

31. Idem.

32. Idem.

33. Nesse sentido é o voto do Min. Gilmar Mendes na ADIn 3.682/MT: "Considerando que o estado de inconstitucionalidade decorrente da omissão pode ter produzido 
a retroatividade seria benéfica, e, por isso, admitida pelo ordenamento constitucional (art. 5. ${ }^{\circ}, \mathrm{XXXVI}$, da CF/1988).

Ocorre que, além de não suprir a omissão conforme determinado pelo $\mathrm{STF}^{34}$ o Poder Derivado Reformador (exercido pelo Congresso Nacional), ao editar a EC 57, usurpou a competência do Judiciário, atribuindo validade (não atribuída nas ações diretas de inconstitucionalidade acima citadas) a atos declarados inconstitucionais, afrontando o princípio da separação de funções.

Admitir a validade da Emenda implica sujeitar a interpretação constitucional do STF ao referendo do Poder Constituinte Reformador, ${ }^{35}$ como ocorria

efeitos no passado - sobretudo se tratar de omissão legislativa -, faz-se mister, muitas vezes, que o ato destinado a corrigir a omissão inconstitucional tenha caráter retroativo. Evidentemente, a amplitude dessa eventual retroatividade somente poderá ser aferida em cada caso. Parece certo, todavia, que, em regra, deve a lei retroagir, pelo menos até à data da decisão judicial em que restou caracterizada a omissão indevida do legislador" (idem, p. 310).

34. Até a presente data não foi editada a Lei Complementar exigida pelo art. 18, § 4. ${ }^{\circ}$, da CF/1988 (Cf. site: [www.planalto.gov.br/ccivil_03/Leis/LCP/Quadro_Lcp.htm]. Acesso em: 19.07.2010).

35. Situação próxima ocorreu no seguinte precedente do STF, mas quanto a Lei: "Improbidade administrativa e prerrogativa de foro. O Tribunal iniciou julgamento de ações diretas de inconstitucionalidade ajuizadas pela Associação Nacional dos Membros do Ministério Público - Conamp e pela Associação dos Magistrados Brasileiros - AMB contra os $\S \S 1 .^{\circ}$ e $2 .^{\circ}$ do art. 84 do CPP, inseridos pelo art. $1 .^{\circ}$ da Lei 10.628/2002. Alega-se ofensa aos arts. 2..$^{\circ}$ 102, I; 105, I; 108, I e 125, \& 1. ${ }^{\circ}$, da CF/1988. Inicialmente, afastou-se, por unanimidade, a preliminar de ilegitimidade da Conamp e a de ausência de pertinência temática das requerentes. Quanto àquela, tendo em conta recente precedente do Pleno no qual se decidira pela legitimação para ação direta de inconstitucionalidade das chamadas 'associações de associações' (AgRg na ADIn 3.153/DF - v. Informativo 356) e, ainda, em virtude de o novo estatuto da Conamp restringir a qualidade de associados efetivos às pessoas físicas integrantes da categoria. Quanto a esta, por se entender que as normas impugnadas se refletem na distribuição vertical de competência funcional entre os órgãos do Poder Judiciário e, por conseguinte, entre os do Ministério Público, o que configuraria a necessária relação de pertinência entre aquelas e as finalidades institucionais das respectivas entidades nacionais de classe. Em relação ao mérito, o Min. Sepúlveda Pertence, relator, julgou procedente o pedido de ambas as ações. Salientou que o $\S 1 .^{\circ}$ do art. 84 do CPP constitui reação legislativa ao cancelamento da Súmula 394, ocorrido no julgamento da QO no Inq 687/SP (DJU 09.11.2001), cujos fundamentos a lei nova estaria a contrariar, e no qual se entendera que a tese sumulada não se refletira na Constituição Federal de 1988 (Enunciado 394 da Súmula: 'Cometido o crime durante o exercício funcional, prevalece a competência especial por prerrogativa de função, ainda que o inquérito ou a ação penal sejam iniciados após a cessação 
daquele exercício'). Asseverou ser improcedente a alegação de que o cancelamento da Súmula 394 se dera por inexistir, à época, previsão legal que a consagrasse, já que tanto a súmula quanto a decisão na QO no Inq 687/SP teriam derivado de interpretação direta e exclusiva da Constituição Federal. Declarou a inconstitucionalidade do $\S 1 .^{\circ}$ do art. 84 do CPP por considerar que o mesmo, além de ter feito interpretação autêntica da Carta Magna, o que seria reservado à norma de hierarquia constitucional, teria usurpado a competência do STF como guardião da Constituição Federal ao inverter a leitura por ele já feita de norma constitucional, o que, se admitido, implicaria sujeitar a interpretação constitucional do STF ao referendo do legislador ordinário. Declarou, também, a inconstitucionalidade do $\S 2 .^{\circ}$ do art. 84 do CPP. Disse que esse parágrafo veiculou duas regras: a que estende a competência especial por prerrogativa de função para inquérito e ação penais à ação de improbidade administrativa e a que manda aplicar, em relação à mesma ação de improbidade, a previsão do $\S 1 .^{\circ}$ do citado artigo. Esta última regra, segundo o relator, estaria atingida por arrastamento pela declaração de inconstitucionalidade já proferida. E a primeira implicaria declaração de competência originária não prevista no rol taxativo da Constituição Federal. Ressaltou que a ação de improbidade administrativa é de natureza civil, conforme se depreende do $\S 4 .^{\circ}$ do art. 37 da CF/1988 ('Os atos de improbidade administrativa importarão a suspensão dos direitos políticos, a perda da função pública, a indisponibilidade dos bens e o ressarcimento ao erário, na forma e gradação previstas em lei, sem prejuízo da ação penal cabível') e que o STF jamais entendeu ser competente para o conhecimento de ações civis, por ato de ofício, ajuizadas contra as autoridades para cujo processo penal o seria. Salientou, ainda, que a Constituição Federal reservou às constituições estaduais, com exceção do disposto nos arts. 29, X e 96, III, a definição da competência dos seus tribunais (art. 125, \& 1. ${ }^{\circ}$, da CF/1988), o que afastaria, por si só, a possibilidade da alteração dessa previsão por lei federal ordinária. Concluiu que o eventual acolhimento, no julgamento da Rcl 2138/DF, da tese de que a competência constitucional para julgar crimes de responsabilidade se estenderia às ações de improbidade, não prejudicaria nem seria prejudicado pela declaração de inconstitucionalidade do $\S 2 .^{\circ}$ do art. 84 , já que a competência dos tribunais para julgar crimes de responsabilidade é bem mais restrita que aquela para julgar os crimes comuns. Após, o Min. Eros Grau pediu vista dos autos. (CPP: 'Art. 84. A competência pela prerrogativa de função é do Supremo Tribunal Federal, do Superior Tribunal de Justiça, dos Tribunais Regionais Federais e Tribunais de Justiça dos Estados e do Distrito Federal, relativamente às pessoas que devam responder perante eles por crimes comuns e de responsabilidade. $\S 1 .^{\circ}$ A competência especial por prerrogativa de função, relativa a atos administrativos do agente, prevalece ainda que o inquérito ou a ação judicial sejam iniciados após a cessação do exercício da função pública. § 2. ${ }^{\circ}$ A ação de improbidade, de que trata a Lei 8.429, de 2 de junho de 1992, será proposta perante o tribunal competente para processar e julgar criminalmente o funcionário ou autoridade na hipótese de prerrogativa de foro em razão do exercício de função pública, observado o disposto no § 1.'” (ADIn 2.797/DF, rel. Min. Sepúlveda Pertence, 22.09.2004. ADIn 2.860/DF, rel. Min. Sepúlveda Pertence, 22.09.2004). Insta lembrar que o parágrafo único do art. 
durante a vigência da Constituição de 1937. Significa a violação da separação de poderes, protegida pelo manto da cláusula pétrea (art. 60, § 4..$^{\circ}$, III, da $\mathrm{CF} / 1988)$, derrubando os efeitos das decisões supracitadas.

Igualmente há manifesta afronta ao princípio da nulidade do ato inconstitucional, da supremacia da Constituição e da segurança jurídica, todos direitos fundamentais, criando perigoso precedente sobre a possibilidade do Congresso Nacional modificar decisões do STF via Emenda Constitucional, pretendendo convalidar algo não passível de convalidação.

Dessa maneira, a EC 57 infringiu a cláusula pétrea da separação de poderes ao perpetuar os efeitos de atos declarados inconstitucionais pelo STF, bem como o princípio da nulidade do ato inconstitucional, a supremacia da Constituição e a segurança jurídica.

\section{CONCLUSÃO}

Com a EC 15, o art. 18, § 4. ${ }^{\circ}$, da CF/1988, passou a exigir Lei Complementar federal para tornar viável a instauração de processos tendentes à criação, à incorporação, à fusão e ao desmembramento de municipalidades.

Passados mais de 13 anos da publicação da referida Emenda Constitucional, a Lei Complementar federal não foi editada.

Vários Municípios foram criados, eleições realizadas, tributos municipais recolhidos, poderes municipais estruturados, domicílios fixados para fins legais etc., ou seja, foram criadas realidades fáticas e jurídicas incompatíveis com a Lei Maior.

Reconhecendo a omissão do legislador, o STF no julgamento da ADIn por omissão 3.682/MT, concedeu prazo de 18 meses para que o Congresso adotasse todas as providências legislativas tendentes ao cumprimento do art. $18, \S 4 .^{\circ}$,

96 da Constituição de 1937 facultava ao Presidente da República, no caso de declaração de inconstitucionalidade de lei necessária ao bem-estar do povo, à promoção ou defesa de interesse nacional de alta monta, submetê-la novamente ao exame do Parlamento, que poderia confirmá-la por dois terços de votos em cada Casa, ficando sem efeito a decisão do Tribunal. Constituição de 1937, art. 96: "Só por maioria absoluta de votos da totalidade dos seus Juízes poderão os Tribunais declarar a inconstitucionalidade de lei ou de ato do Presidente da República. Parágrafo único. No caso de ser declarada a inconstitucionalidade de uma lei que, a juízo do Presidente da República, seja necessária ao bem-estar do povo, à promoção ou defesa de interesse nacional de alta monta, poderá o Presidente da República submetê-la novamente ao exame do Parlamento: se este a confirmar por dois terços de votos em cada uma das Câmaras, ficará sem efeito a decisão do Tribunal". 
da CF/1988. E, ao declarar a inconstitucionalidade das leis estaduais nas Ações Diretas de Inconstitucionalidade 2.240/BA, 3.316/MT, 3.489/SC e 3.689/PA, modulou os efeitos de sua declaração por 24 meses para que as leis estaduais que criassem Municípios ou alterassem seus limites territoriais continuassem vigendo, até que a Lei Complementar federal fosse promulgada contemplando as realidades desses Municípios.

Ocorre que, além de não suprir a omissão conforme determinado pelo STF, o Legislativo, editou a EC 57, pretendendo convalidar os atos de criação, fusão, incorporação e desmembramento de Municípios, cuja lei tenha sido publicada (até 31.12.2006).

Tendo em vista a adoção do princípio da nulidade do ato inconstitucional, o sistema jurídico brasileiro não contempla a figura da constitucionalidade superveniente ou convalidação do ato inconstitucional, sendo, portanto, inconstitucional a EC 57 por afrontar aos princípios constitucionais da nulidade do ato inconstitucional, da supremacia da Constituição e da segurança jurídica.

Além de que, a EC 57 usurpou a competência do Judiciário, atribuindo validade (não atribuída nas ações diretas de inconstitucionalidade acima citadas) a atos declarados inconstitucionais, infringindo a separação de poderes protegida pelo manto da cláusula pétrea (art. 60, § 4. ${ }^{\circ}$, III, da CF/1988), e derrubando os efeitos das decisões judiciais supracitadas.

Assim, apesar da nobre intenção do Congresso Nacional de regularizar a situação de diversos Municípios, a EC 57 é inconstitucional e cria precedente favorável à convalidação dos atos inconstitucionais pelo Congresso Nacional, no exercício da competência reformadora, afrontando os princípios constitucionais da nulidade do ato inconstitucional, da supremacia da Constituição, da segurança jurídica e da separação de funções. A edição da Lei Complementar exigida pelo art. 18, § 4. ${ }^{\circ}$, da Lei Maior, constitui a única maneira de se proceder à solução do problema em respeito ao Texto Supremo, nada impedindo a retroatividade, já que benéfica, não incidindo a vedação do art. 5. ${ }^{\circ}$, XXXVI, da CF/1988, afinal "os fins não justificam os meios" 36 no Estado Democrático de Direito.

\section{Bibliografia}

Agra, Walber de Moura. Curso de direito constitucional. Rio de Janeiro: Forense, 2006.

Alexy, Robert. El concepto de validez em el derecho. Barcelona: Gedisa, 1997.

36. STF, MC no HC 95.037, rel. Min. Celso de Mello, DJE 25.06.2008. 
. Derecho y razón práctica. Ciudad de México: Distribuiciones Fontanamara, 1993.

. Jürgen Habermas - Theory of legal discourse. Cardozo Law Review. n.17. p. 1027-1034. New York: University of California Press, mar. 1996.

Araújo, Luiz Alberto David; Nunes Júnior, Vidal Serrano. Curso de direito constitucional. 4. ed. São Paulo: Saraiva, 2001.

Atienza, Manuel. Contribución a una teoria de la legislación. Madrid: Civitas, 1997.

Ataliba, Geraldo. Regime tributário e Estado de Direito. Disponível em: [www. trf3.jus.br/palestra03.htm]. Acesso em 28.09.2001.

Ávila, Ana Paula Oliveira. A modulação de efeitos temporais pelo STF no controle de constitucionalidade. Porto Alegre: Livraria do Advogado, 2009.

Azambuja, Carmen Luiza Dias de. Controle judicial e difuso de constitucionalidade no direito brasileiro e comparado. Porto Alegre: Sergio Antonio Fabris Ed., 2008.

Baleeiro, Aliomar. Direito tributário brasileiro. Atual. por Misabel Derzi. Rio de Janeiro: Forense, 1999.

. Limitações constitucionais ao poder de tributar. 7. ed. Rio de Janeiro: Forense, 1997.

BArbosa, Daniel. Quando o STF opta pela eficácia prospectiva das decisões de inconstitucionalidade? Revista CEJ. n. 43. ano XII. p. 4-11. Brasília: CEJ, out.-dez. 2008.

Barbosa, Ruy. Os atos inconstitucionais do Congresso e do Executivo. In: ; CÂmara, José Gomes Bezerra. Trabalhos Jurídicos. Rio de Janeiro: Casa de Rui Barbosa, 1962.

BARros, Suzana de Toledo. O princípio da proporcionalidade e o controle de constitucionalidade das leis restritivas de direitos fundamentais. 2. ed. Brasília: Brasília Jurídica, 2000.

Barroso, Luís Roberto. Interpretação e aplicação da Constituição. São Paulo: Saraiva, 1996.

Bastos, Celso Ribeiro. Curso de direito constitucional. São Paulo: Celso Bastos Ed., 2002.

. Hermenêutica e interpretação constitucional. São Paulo: Celso Bastos Ed., 1997.

Bernardes, Juliano Taveira. Controle abstrato de constitucionalidade: elementos materiais e princípios processuais. São Paulo: Saraiva, 2004.

Betti, Emilio. Interpretazione della legge e degli atti giuridici. Milano: Giuffrè, 1949.

Binenbojm, Gustavo. A democratização da jurisdição constitucional e o contributo da Lei n. 9.868/99. Leituras complementares - Controle de constitucionalidade e hermenêutica constitucional. 2. ed. Salvador: JusPodivm, 2008. 
A nova jurisdição constitucional brasileira: legitimidade democrática e instrumentos de realização. Rio de Janeiro: Renovar, 2001.

Bittencourt, Carlos Alberto Lúcio. O controle jurisdicional da constitucionalidade das leis. Rio de Janeiro: Forense, 1949.

Blasco Soto, Maria del Carmen. La sentencia en la cuestión de inconstitucionlidad. Barcelona: José Maria Bosch, 1995.

Bоввıо, Noberto. O positivismo jurídico: lições de filosofia do direito. Trad. Marcio Plugliesi. São Paulo: Ícone, 1995.

; Matteucci, Nicola; Pasquino, Gianfranco. Dicionário de política. Trad. Carmen Varrialle et al. 8. ed. Brasília: UNB, 1995. vol. 1.

Bonavides, Paulo. Curso de direito constitucional. 9. ed. São Paulo: Malheiros, 2000.

Bork, Robert H. The original understanding. In: Sinnott-Armstrong, Walter; BRISON, Susan J. (orgs.). Contemporary perspectives on constitutional interpretation. Boulder/San Francisco/Oxford: Westview Press, 1993.

Bornholdt, Rodrigo Meyer. Métodos para resolução do conflito entre direitos fundamentais. São Paulo: Ed. RT, 2005.

Boucault, Carlos Eduardo de Abreu; Rodriguez, José Rodrigo (orgs.). Hermenêutica plural. São Paulo: Martins Fontes, 2002.

BuzAid, Alfredo. Da ação direta de declaração de inconstitucionalidade no direito brasileiro. São Paulo: Saraiva, 1958.

Canotilho, José Joaquim Gomes. Direito constitucional. 4. ed. Coimbra: Almedina, 1989.

6. ed. Coimbra: Almedina, 1993.

; Moreira,Vital. Constituição da república portuguesa anotada. 3. ed. Coimbra: Coimbra Ed., 1993.

Cappelletti, Mauro. O controle judicial de constitucionalidade das leis no direito comparado. 2. ed. Porto Alegre: Sergio Antonio Fabris Ed., 1992.

. Juízes legisladores? Trad. de Carlos Alberto Álvaro de Oliveira. Porto Alegre: Sergio Antonio Fabris Ed., 1993.

Castro, Carlos Roberto Siqueira de. O devido processo legal e os princípios da razoabilidade e da proporcionalidade. Rio de Janeiro: Forense, 2006.

Cavalli, Cássio Machado. A compreensão jurídica do dever da razoabilidade. Revista de Direito Constitucional e Internacional. vol. 50. p. 220-243. São Paulo: Ed. RT, jan.-mar. 2005.

Cernicchiaro, Luiz Vicente. Direito penal na Constituição. 3. ed. São Paulo. Ed. RT, 1995.

Cintra, Antonio Carlos de Araújo; Grinover, Ada Pellegrini; Dinamarco, Cândido Rangel. Teoria geral do processo. 10. ed. São Paulo: Malheiros, 1994.

CLÈve, Clèmersom Merlin. A fiscalização abstrata da constitucionalidade no direito brasileiro. 2. ed. São Paulo: Ed. RT, 2000. 
Cretella Jr., José. Elementos de direito constitucional. 4. ed. São Paulo: Ed. RT, 2000.

Cruz e Tucci, José Rogério. Aspectos processuais da denominada ação declaratória de constitucionalidade. In: Martins, Ives Gandra da Silva; Mendes, Gilmar Ferreira (coords). Ação declaratória de constitucionalidade. São Paulo: Saraiva, 1994.

CunHa, Leandro José Carneiro da. Notas sobre o princípio da proporcionalidade no processo civil. Revista Dialética do Direito Processual. n. 34. p. 69-78. São Paulo: Dialética, jan. 2006.

Cunha Júnior, Dirley da. Controle de constitucionalidade: teoria e prática. 3. ed. Salvador: JusPodivm, 2008.

4. ed. Salvador: JusPodivm, 2010.

Dantas, Ivo. O valor da constituição: do controle da constitucionalidade como garantia da supralegalidade constitucional. 2. ed. Rio de Janeiro: Renovar, 2001.

Dantas, F. C. de San Tiago. Problemas de direito positivo. Rio de Janeiro: Forense, 1953.

DiAs, Ronaldo Bretãs de Carvalho. Direito à jurisdição eficiente e garantia da razoável duração do processo na reforma do judiciário. Revista de Processo. vol. 128. p. 164-174. São Paulo: Ed. RT, out. 2005.

Dimoulis, Dimitri; Martins, Leonardo. Teoria geral dos direitos fundamentais. São Paulo: Ed. RT, 2007.

. Valores entram em conflito? A perspectiva de um ouriço. Trad. de Emílio Peluso Neder e Alonso Reis Siqueira Freira. Revista do Tribunal de Contas de Minas Gerais. n. 3. ano XXV. Belo Horizonte: TCMG Ed., 2007.

Enterría, Eduardo Garcia de. La Constitución como norma y el Tribunal Constitucional. 3. ed. Madrid: Civitas, 2001.

Ferrari, Regina Maria Macedo Nery. Efeitos da declaração de inconstitucionalidade. 4. ed. São Paulo: Ed. RT, 1999.

Ferreira, Aurélio Buarque de Holanda. Novo Aurélio século XXI - O dicionário da língua portuguesa. Rio de Janeiro: Nova Fronteira, 1999.

Ferreira, Olavo Augusto Vianna Alves. Controle de constitucionalidade e seus efeitos. São Paulo: Método, 2005.

Fiuza, Ricardo Arnaldo Malheiros. Direito constitucional comparado. 3. ed. Belo Horizonte: Del Rey, 1997.

Francisco, José Carlos. Convalidação de norma inconstitucional e constitucionalidade superveniente - Impossibilidade. Disponível em: [www.ibec.inf.br/ jose.pdf]. Acesso em: 14.07.2010.

GóEs, Gisele Santos Fernandes. Princípio da proporcionalidade no processo civil. São Paulo: Saraiva, 2004.

Grinover, Ada Pellegrini. Controle da constitucionalidade. Revista Forense. vol. 341. p. 3-12. Rio de Janeiro: Forense, 1998. 
GraU, Eros Roberto. A Constituição brasileira e as normas programáticas. Revista de Direito Constitucional e Ciência Política. n. 4. p. 40 e ss. Rio de Janeiro: Forense, 1985.

Guimarães, Deocleciano Torrieri. Dicionário técnico jurídico. 4. ed. São Paulo: Rideel, 2001.

GÜNTHER, Klaus. Un concepto normative de coherencia para uma teoria de la argumentación jurídica. Trad. Juan Carlos Velasco Arroyo. Doxa. n. 17-18. p. 271-302. Alicante: Universidade de Alicante, 1995.

HÄBERle, Peter. Hermenêutica constitucional: a sociedade aberta dos intérpretes da Constituição: contribuição para a interpretação pluralista e procedimental da constituição. Trad. Gilmar Ferreira Mendes. Porto Alegre: Sergio Antonio Fabris Ed., 1997.

Del uso pragmático, ético y moral de la razón prática. Aclaraciones a la ética del discurso. Trad. José Mardomingo. Madrid: Trotta, 2000.

Hesse, Konrad. A força normativa da Constituição. Trad. Gilmar Mendes. Porto Alegre: Sergio Antonio Fabris Ed., 1991.

HöFfe, Otfried. Immanuel Kant. Trad. Cristian Viktor Hamm e Valério Rohden. São Paulo: Martins Fontes, 2005.

Horta, Raul Machado. Direito constitucional. 2. ed. Belo Horizonte: Del Rey, 1999.

Houaiss, Antônio; Villar, Mauro de Salles. Dicionário Houaiss de língua portuguesa. Rio de Janeiro: Objetiva, 2001.

Kelsen, Hans. A garantía jurisdiccional da constituição (a justiça constitucional). Direito Público. n. 1. vol. 1. p. 90-130. Brasília: IOB, jul.-set. 2003.

. Jurisdição constitucional. Trad. Alexandre Krug, Eduardo Brandão e Maria Ermantina Galvão. Revisão técnica Sérgio Sérvulo da Cunha. São Paulo: Martins Fontes, 2003.

Larenz, Karl. Metodologia da ciência do direito. Trad. José Lamego. 3. ed. Lisboa: Fundação Calouste Gulbenkian, 1997.

Leite, Eduardo de Oliveira. Monografia jurídica. 7. ed. São Paulo: Ed. RT, 2006.

Lenza, Pedro. Direito constitucional esquematizado. 11. ed. São Paulo: Método, 2007.

LunARDI, Soraya Gasparetto. Modulação temporal dos efeitos no processo de controle de constitucionalidade e influência de argumentos econômicos. $n$. 9. ano 3. p. 209-229. Revista Brasileira de Estudos Constitucionais. Belo Horizonte: Fórum, jan.-mar. 2009.

Maciel, Adhemar Ferreira; Bastos, Celso Ribeiro. Comentários à Constituição do Brasil. São Paulo: Saraiva, 1997. vol. 4.

; Mendes, Gilmar Ferreira (coords.). Ação declaratória de constitucionalidade. São Paulo: Saraiva, 1994. 
Marques, Gérson. O Supremo Tribunal Federal na crise institucional brasileira. Fortaleza: ABC, 2001.

Martins, Ives Gandra da Silva; Mendes, Gilmar Ferreira. Controle concentrado de constitucionalidade: comentários à Lei 9.868, de 10.11.1999. 1. ed. São Paulo: Saraiva, 2001.

3. ed. São Paulo: Saraiva, 2009.

Martins, Ricardo Marcondes. Efeitos dos vícios do ato administrativo. São Paulo: Malheiros, 2008.

Maximiliano, Carlos: Hermenêutica e aplicação do direito. 7. ed. São Paulo: Freitas Bastos, 1961.

Medeiros, Rui. A decisão de inconstitucionalidade. Lisboa: Universidade Católica, 1999.

Melo, Marconi Antas Falcone de. Justiça constitucional: o caráter jurídico-político das decisões do STF. Rio de Janeiro: Forense; São Paulo: Método, 2008.

Mendes, Conrado Hübner. Controle de constitucionalidade e democracia. Rio de Janeiro: Elsevier, 2008.

Mendes, Gilmar Ferreira. Anteprojeto de lei sobre processo e julgamento da ação direta de inconstitucionalidade e da ação declaratória de constitucionalidade. Revista de Direito Constitucional e Internacional. vol. 29. p. 24-36. São Paulo: Ed. RT, out.-dez. 1999.

. A ação declaratória de constitucionalidade: a inovação da Emenda Constitucional n. 3 de 1993. São Paulo: Saraiva, 1994.

. Controle de constitucionalidade: aspectos jurídicos e políticos. São Paulo: Saraiva, 1990.

. Direitos fundamentais e controle de constitucionalidade: estudos de direito constitucional. 2. ed. São Paulo: Celso Bastos Ed., 1999.

. Jurisdição constitucional. 2. ed. São Paulo: Saraiva, 1998.

; Coelho, Inocêncio Mártires; Branco, Paulo Gustavo Gonet. Curso de direito constitucional. 2. ed. São Paulo: Saraiva, 2007.

3. ed. São Paulo: Saraiva, 2008.

Meyer, Emílio Peluso Neder. A decisão no controle de constitucionalidade. São Paulo: Método, 2008.

Miranda, Jorge. Manual de direito constitucional. 2. ed. Coimbra: Coimbra Ed., 1983.

Moraes, Alexandre de. Jurisdição constitucional e tribunais constitucionais: garantia suprema da constituição. São Paulo: Atlas, 2000.

Morais, Carlos Blanco de. Justiça constitucional. Coimbra: Coimbra Ed., 2002. t. I.

Müller, Friedrich. Métodos de trabalho do direito constitucional. Trad. Peter Naumann. 2. ed. São Paulo: Max Limonad, 2000. 
O significado teórico de "constitucionalidade/inconstitucionalidade" e as dimensões temporais das declarações de leis no direito alemão. Trad. Peter Naumann. Disponível em: [www.rio.rj.gov.br/pgm]. Acesso em: 20.10.2004.

Nascimento, Carlos Valder do. Coisa julgada inconstitucional. 2. ed. Rio de Janeiro: América Jurídica, 2000.

Nobre Júnior, Edílson Pereira. O direito processual brasileiro e o efeito vinculante das decisões dos tribunais superiores. Revista dos Tribunais. vol. 785. p. 46. São Paulo: Ed. RT, mar. 2001.

Otero, Paulo. Ensaio sobre o caso julgado inconstitucional. Lisboa: Lex, 1993.

Palu, Oswaldo Luiz. Controle de constitucionalidade: conceitos, sistemas e efeitos. 2. ed. São Paulo: Ed. RT, 2001.

Paulo, Vicente; Alexandrino, Marcelo. Controle de constitucionalidade. Rio de Janeiro: Forense; São Paulo: Método, 2008.

Pelicioli, Angela Cristina. A sentença normativa na jurisdição constitucional: $o$ Supremo Tribunal Federal como legislador positivo. São Paulo: Ed. LTr, 2008.

Polleti, Ronaldo. Controle da constitucionalidade das leis. Rio de Janeiro: Forense, 1985.

Ramos, Elival da Silva. A inconstitucionalidade das leis: vício e sanção. São Paulo: Saraiva, 1994.

Radbruch, Gustav. Introdução à filosofia do direito. Coimbra: Armênio Amado Ed., 1961.

Sampaio, José Adércio Leite. A constituição reinventada pela jurisdição constitucional. Belo Horizonte: Del Rey, 2002.

; Cruz, Álvaro Ricardo de Souza. Hermenêutica e jurisdição constitucional. Belo Horizonte: Del Rey, 2001.

SAntos, Gustavo Ferreira. O princípio da proporcionalidade na jurisprudência do Supremo Tribunal Federal: limites e possibilidades. Rio de Janeiro: Lumen Júris, 2004.

SARMEnto, Daniel. A eficácia temporal das decisões no controle de constitucionalidade, hermenêutica e jurisdição constitucional. Belo Horizonte: Del Rey, 2001.

. A ponderação de interesses na Constituição Federal. Rio de Janeiro: Lumen Juris, 2000.

SCHAFFer, Heinz. Austria: la relación entre el Tribunal constitucional y el legislador. In: AJA, Eliseo (coord.). Las tensiones entre el Tribunal constitucional y el legislador em la Europa actual. Barcelona: Ariel, 1998.

Schlink, Bernhard. The dynamics of constitucional adjudication. Cardozo Law Review. n. 4 e 5. vol. 17. p. 1231-1238. New York: Yeshiva University, mar. 1996.

Schmitt, Carl. La defensa de la Constituciòn. Madrid: Tecnos, 1998.

. Teoria de la Constituciòn. Madrid: Alianza Ed., 2001. 
SESMA, Victoria Iturralde. El precedente em el common law. Madrid: Civitas, 1995.

Silva, José Afonso da. Aplicabilidade das normas constitucionais. 5. ed. São Paulo: Malheiros, 2001. 6. ed. São Paulo: Malheiros, 2003. . Curso de direito constitucional positivo. 11. ed. São Paulo: Malheiros, 1996. . Da jurisdição constitucional no Brasil e na América Latina. Revista da Procuradoria Geral do Estado de São Paulo. vol. 13-15. p. 105. São Paulo: Centro de Estudos PGE-SP, 1989. . O proporcional e o razoável. Revista dos Tribunais. vol. 798. p. 23-50 São Paulo: Ed. RT, abr. 2002.

Siqueira Júnior, Paulo Hamilton. Controle de constitucionalidade. São Paulo: Juarez de Oliveira Ed., 2001.

SLerCA, Eduardo. Os princípios da razoabilidade e da proporcionalidade. Rio de Janeiro: Lumen Juris, 2002.

STRECK, Lenio Luiz. Jurisdição constitucional e hermenêutica: uma nova crítica do direito. Porto Alegre: Livraria do Advogado, 2002.

Tavares, André Ramos. Curso de direito constitucional. 5. ed. rev. e atual. São Paulo: Saraiva, 2007. . Teoria da justiça constitucional. São Paulo: Saraiva, 2005.

- Tratado da arguição de preceito constitucional fundamental: (Lei n. 9.868/99 e Lei n. 9.882/99). São Paulo: Saraiva, 2001.

. Tribunal e jurisdição constitucional. São Paulo: Celso Bastos Ed., 1998.

; Rothenburg, Walter Claudius (orgs.). Argüição de descumprimento de preceito constitucional fundamental: análises à luz da Lei n. 9882/99. São Paulo: Atlas, 2001.

Temer, Michel. Elementos de direito constitucional. 12. ed. São Paulo: Malheiros, 1996.

Veloso, Zeno. Controle jurisdicional de constitucionalidade. 2. ed. Belo Horizonte: Del Rey, 2000.

Verdú, Pablo Lucas. Teoria de la Constitución como ciência cultural. 2. ed. rev. e aum. Madrid: Dykinson, 1998.

Villalón, Pedro Cruz. La formacion del sistema Europeo de control de constitucionalidad (1918-1939). Madri: Centro de Estudios Constitucionales, 1987.

VIEIRA, Oscar Vilhena. Supremo Tribunal Federal: jurisprudência política. 2. ed. São Paulo: Malheiros, 2002.

Willoughby, Westel Woodbury. The constitutional law of the United States. New York: Nabu Press, 1910. vol. 1.

Zavascki, Teori Albino. Eficácia das sentenças na jurisdição constitucional. São Paulo: Ed. RT, 2001. 


\section{Pesquisas do Editorial}

\section{Veja também Doutrina}

- Da impossibilidade de emenda constitucional convalidar lei inconstitucional, de Américo Bedê Freire Júnior - RTrib37/136; e

- 0 retalhamento da Constituição de 1988, de Arx Tourinho - RDCl31/181.

\section{Veja também Jurisprudência}

- Convalidação do ato de criação de município por meio de lei estadual, após a inobservância da vedação imposta pela EC 15/1996: RT909/342. 